\title{
Entrepreneurs of Grievance
}

\section{Drivers and Effects of Indonesia's Islamist Mobilization}

\author{
Marcus Mietzner \\ Australian National University \\ marcus.mietzner@anu.edu.au \\ Burhanuddin Muhtadi \\ Syarif Hidayatullah State Islamic University \\ burhanuddin.muhtadi@uinjkt.ac.id \\ Rizka Halida \\ University of Indonesia \\ rizka@ui.ac.id
}

\begin{abstract}
There has been much scholarly debate on the causes and effects of Islamist mobilizations. As some authors involved in this debate have identified rising Islamist attitudes among Muslims as a main cause of Islamist mobilizations, our study advances detailed research of opinion survey data as the best methodology to verify or falsify this assertion. Discussing the case of Indonesia, we use original survey data sets to show that prior to the 2016 Islamist mobilization there, Islamist attitudes were in fact moderating. This means that hardening Islamist views in the Muslim population could not have caused the mobilization. Importantly, however, we can demonstrate that Islamist political attitudes increased after the mobilization, and they did so consistently around the themes propagated by its organizers. This supports theories of religio-political entrepreneurs being the main drivers of Islamist mobilizations. Grievances and religious beliefs, on the other hand, are necessary yet insufficient conditions for such actions.
\end{abstract}

\section{Keywords}

Islam - democracy - Indonesia - political attitudes - public opinion

(C) MARCUS MIETZNER, BURHANUDDIN MUHTADI AND RIZKA HALIDA, 
Since the late 1970s, scholars of political Islam have debated the causes of Islamist mobilizations in majority Muslim countries. The Islamist revolution in Iran in 1979 marked the beginning of a series of Islamist mobilizations, as well as an accompanying academic debate about their drivers. Some authors have argued that such mobilizations, which can occur in the form of electoral challenges and street protests or a combination of both, are primarily caused by socio-religious and politico-economic grievances among underprivileged Muslims (Wickham 2002; Esposito and Mogahed 2008; Fuller and Kurpershoek 2005; Roy 2017); others have viewed Islamist mobilizations as inherent to Islam itself, forming part of its doctrine of struggle (Bouyahya 2015; Tibi 2014; Kepel 2006); and others again have put more emphasis on the role of religio-political entrepreneurs, who exploit specific sets of grievances to push for an Islamist agenda (Eligür 2010; Mecham 2017).

While most of these approaches focus in one way or another on the attitudes of Muslims and their role in Islamist mobilizations (whether as drivers or post-event effects), only few publications have systematically analysed these attitudes. If such studies exist, they are often one-off surveys, allowing for no longitudinal comparisons over time (Esposito and Mogahed 2008; Pew Research Center 2013). This is despite the fact that the systematic study of multi-year opinion poll data can tell us much about a) whether rising or newly emerging grievances caused Muslims to join Islamist mobilizations; and/or b) whether such attitudes and motivations changed as the result of mobilizations, pointing to the ability of religio-political entrepreneurs to manipulate religious views. The reason for the under-usage of survey data analysis in studying Islamist mobilizations is mostly practical: many Muslim majority countries do not have long-established survey institutes that possess credible data sets for multi-year periods (partly because there are few majority Muslim countries that are enduring democracies), and globally operating research institutes are often reluctant to run regular surveys in locations other than their main foci of political and financial interest.

Against this background, Indonesia constitutes a well-suited case study to explore the drivers (and effects) of Islamist mobilizations. To begin with, Indonesia is the country with the largest Muslim population in the world, and has a long history of Islamist activism (Hadiz 2016; Hadiz and Robison 2017). Importantly, Indonesia experienced a massive Islamist mobilization in late 2016 and early 2017, combining both street demonstrations and an electoral challenge (in this case, for the governorship of the capital). This mobilization has been recognized as an important shift in Indonesian politics (Lindsey 2017), and is set to have long-term repercussions. Further, the distinct time frame of the mobilization in 2016 and 2017 allows us to clearly distinguish between the pre- 
mobilization period, the mobilization itself, and the post-mobilization phase. We possess survey data for all these periods of the mobilization, making it possible to identify potential causes and effects. Moreover, since the Islamist mobilization in Indonesia had a strong central message - namely, the exclusion of non-Muslims from leading political office and the obligation for Muslims to vote for Muslim candidates - we can assess the extent to which this message of the mobilization organizers took root as a possible effect of the mobilization. Finally, comparing pre- and post-mobilization survey data makes it possible, in the Indonesian case, to study which demographics were particularly vulnerable to this mobilization narrative.

Based on the analysis of our data, we argue that while important grievances were present among the Muslim population prior to the 2016 events, these were only a necessary, but overall insufficient, condition for the Islamist mobilization. Indeed, many of the attitudes associated with such grievances (most notably, intolerance towards non-Muslims) were moderating before 2016, and thus could not have been responsible for the mobilization. Rather, we demonstrate that the success of the Islamist mobilization can be mainly ascribed to the ability of religio-political entrepreneurs to rally around an effective narrative. We substantiate this argument by showing that Muslim attitudes surrounding the main message of the mobilization (that is, the exclusion of non-Muslims from political office) significantly hardened during and after the mobilization, while other attitudes of intolerance unrelated to the mobilization continued to soften. This suggests that many Muslims absorbed the message propagated by the mobilization leaders. We also explain that many of those who were drawn to the mobilization narrative-or those who radicalized between the pre- and post-mobilization periods - were Muslims from lower socio-economic strata. Hence, we find in the Indonesian case much evidence for the religio-political entrepreneurship approach to explaining Islamist mobilization, confirming some - but not all —of the theses developed by Quinn Mecham (2017) in this regard.

We develop our arguments in six separate analytical steps. First, we briefly review the debate on the causes of Islamist mobilizations, define key terms, and explain our methodology. Second, we introduce the Indonesian case as an example of a significant Islamist mobilization. Third, we trace the development of important attitudes among Indonesian Muslims prior to, during, and after the mobilization. These attitudes relate to intolerance towards nonMuslims, specific perceptions of Muslim deprivation, and support for militant Islamist groups. This approach allows us to pinpoint important changes that occurred after the mobilization, and thus to nominate possible causes and effects much more systematically than other studies. Fourth, we look at the 
demographic profiles of those attracted to the ideas of the mobilization, comparing pre- and post-mobilization characteristics and delivering insights into recruitment patterns during the protests. Fifth, we briefly review the government's response to the mobilization, and highlight those aspects that worked to contain its repercussions and those that did not. Finally, we draw conclusions from the Indonesian case for the comparative debate on Islamist mobilizations.

\section{Islamist Mobilization: Definitions, Debate, and Methodology}

Before we review the debate on causes and effects of Islamist mobilizations, we need to define the key terms. These key terms are 'Islamist' and 'mobilization', as well as their combination as 'Islamist mobilization'. While there is a wide variety of definitions of these routinely contested categories, we decided to largely follow Mecham's conceptualizations. For Mecham (2017:12), the term 'Islamist' denotes a 'self-defined Islamic religious agenda [that is pursued] through engagement with the state.' 'Mobilization', on the other hand, 'includes activities that seek to influence state policy or to influence the balance of state power' (Mecham 2017:12). Mecham then further sharpens the definition of these terms for their combination into the overall concept of 'Islamist political mobilization', which he defines as 'attempts by self-defined Islamist actors to align state policy with perceived Islamic principles or to capture a portion of state power' (Mecham 2017:38). In his model, this mobilization can include, in its most mainstream manifestation, voting for Islamically oriented parties and candidates; participating in Islamist-inspired street demonstrations; and, in its most narrow form, violence. We adopt the first two of Mecham's components of Islamist mobilization for our understanding of the concept; we do not view violent struggle against the existing state structures (for instance, as practised by the Taliban) as a form of Islamist political mobilization-for such violent acts, we reserve the term 'Islamist insurgency'.

In the debate on the causes of Islamist mobilizations, three broad schools of thought can be distinguished. The first focuses on grievances among the Muslim population (Esposito and Mogahed 2008; Fuller and Kurpershoek 2005). These grievances may be of a religio-theological nature (for instance, the conviction that non-believers contaminate the sanctity of the Islamic faith), or have socio-economic or political connotations (for example, the belief that Muslims are worse off economically than non-Muslims, or that Muslims are victimized in conflicts around the world). Often, these grievances are seen as part of structural developments, such as globalization; the cultural dominance 
of the West; Chinese 'infiltration' of Muslim majority countries in Asia; economic imbalances; and other similar contexts. In a political-economy analysis of these grievances, some scholars have highlighted changing social bases of Islamist activism as a key driver of mobilization (Hadiz 2016:8). In its strictest version, however, the grievance-based approach has separated Muslim core complaints from Islamism (and, indeed, Islam) itself. Olivier Roy (2017), forinstance, has asserted that it is not Islam(ism) that breeds radicalism; rather; Islamism draws from, and forms around, radicalism fed by grievances.

In contrast to the 'grievance scholars', other authors have identified mobilization as an integral part of the Islamic religion and its doctrines. Different from the secularized religions of the West and in Asia, Islam is seen by some scholars as having a built-in call for struggle and mobilization (Waardenburg 2002). In this conceptualization, Islamist mobilization is not a reaction to external factors and influences - it is, as a religious doctrine, a proactive driver of protest against a secular world seen as necessarily and eternally inadequate (Murphy 2002; Bouyahya 2015; Tibi 2014). In his famous debate with Roy, Gilles Kepel (2006) expressed this argument most forcefully, putting the notion of the 'radicalization of Islam' against Roy's assertion of the 'Islamization of radicalism'.

A third school, represented by Mecham, has emphasized the role of religiopolitical entrepreneurs in exploiting existing contexts to advance Islamist agendas. For Mecham (2017:7), Islamist mobilization emerges when—against the background of commonly shared Islamic knowledge - religious entrepreneurs use focal, state-related events to rally support for Islamist causes. In other words, religious entrepreneurs have the choice of whether to use existing contexts and events (such as elections) for Islamist mobilization or not. This approach does not downplay the power of grievances, but does not ascribe the character of path dependence to them. Similarly, it acknowledges the importance of the Islamic faith as the basis for mobilization, but does not view Islam as the engine of mobilization itself; that engine is in the hands of religiopolitical leaders, who can either opt to mobilize or not mobilize.

We believe that one of the best ways to verify the hypotheses developed by the various schools is to analyse multi-year opinion poll data on religiopolitical attitudes among the Muslim population. No other approach can so systematically assess the content and strength of grievances among Muslims, and no other methodology can establish with such precision whether religiopolitical entrepreneurs are able to entrench their narrative in the wider community of believers. Similarly, it is only through data analysis from before, during, and after the mobilization that broader assessments on its drivers can 
be made. Most importantly, by looking at such multi-year data sets, we can explore whether grievances caused the mobilization or, on the contrary, the mobilization hardened grievances. Therefore, while we appreciate other, more qualitative approaches and view them as complimentary to our work, we base our analysis here primarily on survey data analysis. With this, we follow an increasing trend towards survey research as a major field of enquiry in political science (Marsden and Wright 2010).

Using survey data for political science research-particularly in a young democracy such as Indonesia-comes with a number of challenges. However, we believe that the validity and reliability of survey data can be protected if certain criteria are met. To begin with, it is crucial to only use survey data from institutes with a proven track record. This track record can be assessed by comparing the organizations' survey and quick-count results against electoral outcomes; in our case, we only used data from institutes whose surveys and quick counts closely resembled the outcome of the election they surveyed. This gives us confidence that the polls on other matters surveyed by these institutes are similarly accurate. Furthermore, it is important to insist on the use of strictly scientific survey methods. This includes issues such as sample size and sample selection, as well as other methodological questions. In terms of sample size, for instance, there is a popular myth that larger sample sizes lead to more reliable results. This is only true up to a certain threshold: for national surveys in Indonesia, this threshold is between 1,500 to 2,00o respondents. Above that threshold, results don't get more accurate, but can in fact be distorted. The highly respected American polling firm Gallup, for instance, uses a sample of 1,500 respondents for its surveys in the United States, which—at 325 millionhas a larger population than Indonesia.

At the same time, it is essential to clearly state the limitations of a national poll. One of these limitations is that it is not possible to reliably analyse the data by province. While the larger provinces have a sufficiently large sample size for proper analysis, the smaller provinces don't. Thus, in our discussion of the national polls we examined and conducted, we focus on national-level analysis rather than local-level investigations. Having said that, even a rudimentary breakdown of our national-level data by provinces - with all its limitationsreveals no surprises: Muslim respondents' intolerance towards non-Muslims, for example, is higher in Aceh, West Sumatra, the Riau Islands, West Java, Banten, and West Nusa Tenggara than in the rest of Indonesia. Based on the religiopolitical profiles of these areas, this was to be expected - and has been confirmed by a recent study using different methods (Sumaktoyo 2018). But while intolerance levels are higher in these areas, they are not excessively so. Other provinces-such as Central and East Java, which host vast populations-also 
have significant levels of Islamist grievances. Hence, while not denying regional diversity (indeed, we view this local variety as a much-studied given), we opted to focus our study on the national level.

With all this in mind, our research relied on three main data sets. First, we had access to multi-year data sets held by the Lembaga Survei Indonesia (LSI, Indonesian Survey Institute) and its partners. These partners include Saiful Mujani Research and Consulting (SMRC) as well as Indikator Politik Indonesia (or 'Indikator'), and we refer to them whenever we use their data. All three organizations belong to the group of survey institutes that we judge as having a good track record, based on the criteria outlined above. In combination, the data sets provided by these institutes cover the period of around 2004 to 2016. Second, we analysed a survey on attitudes of intolerance among the Muslim population conducted by the LSI in March 2016. ${ }^{1}$ Crucially, this survey was done six months before the Islamist mobilization commenced, allowing us to establish the 'zero point' against which later post-mobilization changes can be measured. The survey had 1,540 respondents, using multistage random sampling (the sample included citizens of all religions, but the data analysis focused on Muslim responses). Third, we decided to re-run the 2016 LSI survey in almost identical form - and using exactly the same methodology—in August 2017, around four months after the Islamist mobilization had peaked. This survey was also carried out by the LSI. It is the comparison between these three data sets, as well as cross tabulations and correlations drawn from them, that form the main foundation of this article.

\section{Indonesia's Islamist Mobilization}

The events of late 2016 and early 2017 in Indonesia's capital Jakarta fit neatly into Mecham's definition of Islamist political mobilizations. This mobilization took the form of street protests organized around a state-related focal point, namely the elections for the governorship of Jakarta. The goal of the mobilization was to advance a distinctly Islamist agenda, namely the removal from office of a Christian-Chinese incumbent - and not only through elections, but through criminal charges associated with a blasphemy allegation. At the same time, the Islamist alliance supported a Muslim candidate to win the elections, and it succeeded with its campaign. The mobilization also led to the imprisonment of the Christian-Chinese incumbent, marking a stunning victory for the

1 The survey was commissioned by the Wahid Institute. 
Islamists and a new phase in Indonesian politics, in which Islamist mass mobilization is set to offer alternative pathways to political influence outside of the established party system.

The details of the mobilization have been described elsewhere, including by the authors (Mietzner and Muhtadi 2018). Suffice to recall here that an assembly of previously disparate Islamist groups-including the Front Pembela Islam (FPI, Islamic Defenders Front), the Indonesian branch of Hizbut Tahrir (HTI, Party of Liberation) and Saudi-inspired Salafi groups such as Wahdah Islamiyah (Islamic Unity) - came together in October 2016 to demand the criminal prosecution of Basuki Tjahaja Purnama (or 'Ahok'), the ChristianChinese governor of Jakarta. The popular Ahok, who ran for re-election in polls scheduled for February 2017, had given a speech in September 2016 that the Islamists viewed as blasphemous. More fundamentally, however, the Islamists objected in principle to non-Muslims holding key political office-a doctrine they claimed to be enshrined in the Quranic verse Al-Maidah $5^{1}$ (not coincidentally, it was this interpretation of the verse that Ahok had disputed in his speech). The Islamists subsequently organized mass demonstrations between November 2016 and March 2017, some of which attracted hundreds of thousands of Muslims from across Indonesia. These protests were unprecedented in size and political significance, and cornered President Joko Widodo (or 'Jokowi'), a close ally of Ahok's. In their campaign, the Islamists called for the election of either Anies Baswedan or Agus Yudhoyono, both Muslim candidates. Anies was eventually elected in a landslide, second-round victory in April 2017.

There was no shortage of religio-political entrepreneurs in the mobilization. To begin with, Rizieq Shihab, the leader of the FPI and the charismatic public face of the mobilization, used the anti-Ahok protests to pursue his broader Islamist agenda. He had agitated against Ahok and other non-Muslims in political positions for a long time, and was fiercely opposed to President Jokowi, whom he viewed as too secular. Other Islamist leaders-such as Bachtiar Nasir and Al-Khaththath — also played key roles. However, equally crucial were mainstream politicians who aligned their interests with those of the Islamists. Most importantly, former President Susilo Bambang Yudhoyono, whose son Agus ran in the elections, openly supported the mobilization. In a high-profile press conference, he called for Ahok's prosecution, and the government found evidence that Yudhoyono's allies helped funding the protests. ${ }^{2}$ Similarly, Prabowo Subianto, who had lost against Jokowi in the 2014 presidential elections, had

2 Interview with a Jokowi government official, Jakarta, 13-11-2016. 
his own candidate, Anies Baswedan, in the Jakarta race. In a symbolic gesture, Prabowo's deputy marched with the protesters in the November 2016 protest. Thus, there was a network of religio-political entrepreneurs that did not only include Islamist figures 'interested in mobilizing others on behalf of Islamist causes', but also mainstream leaders 'with strong political interests such as opposition to the regime or a desire for power' (Mecham 2017:41).

The narrative of the Islamist mobilization was centred on two main messages. The primary message, framed within the parameters of Al-Maidah 51, was that political positions should be reserved for Muslims, and that Muslims had an obligation to vote for Muslim candidates. The propagandistic core of this narrative was the claim that Ahok had committed blasphemy by questioning the sanctity of this Quranic doctrine. In developing their narrative, the Islamists drew from, and fed into, long-standing grievances among Indonesian Muslims that non-Muslims, and ethnic Chinese in particular, hold a disproportionate amount of influence over the state (Setijadi 2017). Hence, the demand that political posts should be unavailable for non-Muslims was not only packaged as doctrinal purity; it was also a populist appeal to Muslim perceptions of political deprivation. The second message built into the mobilization was that of economic inequality between Muslims and non-Muslims. This message grew stronger towards the end of the anti-Ahok protests as it became clear that Islamist leaders had to identify new topics for further mobilization. Benefitting from the reality of ethnic Chinese dominance of the upper echelons of the private economy, the inequality theme resonated well with many Muslims. This clear exposition of the mobilization messages not only gave the movement a clear purpose; it also allows us to explore how support levels for the messages were influenced by the mobilization.

There has been a wide variety of approaches to interpreting the Islamist mobilization of 2016 and 2017. To begin with, Greg Fealy (2016) doubted that they constituted a case of Islamist mobilization at all. For him, the protests were about a single collective grievance, namely Ahok's blasphemy. After the December 2016 demonstration, he wrote that 'there are good reasons to doubt that [the protest] does mark some conservative surge. To begin with, only a minority appeared to be affiliated with known Islamist groups or drawn to the more ideological Islamist messages in the rally.' He continued that 'for the great majority, this was primarily a religious event, $[\ldots]$ and many $[\ldots]$ rejected on principle attempts to Islamize the Constitution and restrict nonMuslim rights'. Others, by contrast, saw the mobilization as 'tip-of-the-iceberg displays of Islamic conservatism that has been emerging in the past 15 years. Beneath this tip lies a huge mound of religious fanaticism' (Assyaukanie (2017). Assyaukanie's approach is similar to that promoted by the school of schol- 
ars who explain Islamist mobilization as a phenomenon driven primarily by Islamic convictions of (radicalized) believers. Others again focused on the interests of entrepreneurs behind the demonstrations, emphasizing the 'manipulation of [religious] intolerance by the small group of elite politicians who dominate Indonesian politics' (Lindsey 2016). Thus, all three main approaches to explaining Islamist mobilizations are present in the Indonesian case.

But what do our data tell us about the causes and effects of the mobilization? Were, as Fealy suggested, Islamist motivations irrelevant? Or were, as claimed by Assyaukanie, religious sentiments the main drivers? Or did, as Lindsey claimed, the entrepreneurs play the most important role in the mobilization? And more generally: how can we distinguish between drivers and effects of the mobilization? The following section - the core segment of this article-will now address these questions.

\section{The Data: Drivers and Effects of the Mobilization}

In a separate publication (Mietzner and Muhtadi 2018), we already presented data showing that a rise in religious grievances and sentiments could not have been responsible for the Islamist mobilization in November 2016. Accordingly, we will only briefly summarize these findings here-mostly based on the pre-mobilization LSI survey of March 2016 and similar surveys done in 2010 and 2011. Three main findings stood out from our analysis of the surveys: first, a significant Islamist-leaning constituency existed prior to the mobilization. Measured by questions about rejection of non-Muslims in political positions and religio-cultural activities of non-Muslims in their neighbourhood, $28 \%$ of Indonesian Muslims could in 2016 be classified as supporting ideas of Islamist exclusivism. Thus, we found it unconvincing to suggest that the 2016 Islamist mobilization was unrelated to the existence of Islamist sentiments. Second, however, we concluded that the timing of the mobilization could not be explained with reference to this pool of Islamist ideas. This is because the majority of survey measures on religious exclusivism recorded a moderation of attitudes among Indonesian Muslims between 2010 and 2016. In other words, Islamist attitudes were declining prior to the 2016 mobilization, not rising. ${ }^{3}$ And third, we found that Islamist attitudes were-in contrast

3 It is important to note that we don't have systematic data on pre-201o trends. However, based on one-off polls and other, more qualitative studies, it is highly probable that conservative and intolerant views among Muslims increased from the late 1980s (when Suharto allowed, 
Do you object to non-Muslims becoming ... (\% Yes)

\begin{tabular}{lccc} 
& $\mathbf{2 0 1 6}$ & $\mathbf{2 0 1 7}$ & Change \\
\hline Regent/Mayor & 39.3 & 47.4 & 8.1 \\
Governor & 40.3 & 48.2 & 7.9 \\
Vice President & 41.4 & 49.6 & 8.2 \\
President & 47.9 & 53.2 & 5.3 \\
& & & \\
Objection index (avg.) & 42.3 & 49.6 & $7 \cdot 3$ \\
\hline
\end{tabular}

to previous years-slightly more pronounced in the upper and middle classes than among the poor, explaining the grown organizational resources and thus potential for elite-led mobilization.

But this analysis of pre-mobilization data only allowed us to make partial assessments of the protests' drivers. While we were able to postulate that rising Islamist attitudes were not responsible for the mobilization, we could say very little about a possible reverse linkage — that is, hardening Islamist views as a result of the mobilization and the opinion-shaping influence of its leaders. Only the inclusion of the 2017 post-mobilization data-collected for the purpose of this article - made it possible to evaluate both potential drivers and impacts.

The most important finding from the 2017 post-mobilization survey is a drastic increase in exclusivist political attitudes among Muslims. These Islamist attitudes relate to Muslims' objections to non-Muslims holding the office of mayor or district head, governor, vice-president, and president (see Table 1). If all measures are averaged into an index of political intolerance, we can establish that $49.6 \%$ of Muslims rejected non-Muslims in political office after the mobilization - an increase of $7.3 \%$ on the pre-mobilization survey. We examined the statistical significance of the difference between the 2016 and 2017 numbers through further tests, and found this to be strong and significant at the $99 \%$ level. (In separate SMRC surveys of Jakarta voters, the increase in

and supported, a partial Islamization of society) to the mid 2ooos, when democratization opened up space for Islamists to practise and spread their beliefs. It is from this high level that trends of intolerance among Muslims, at least in specific categories, began to fall from the 2010 s onwards. 
Islamist exclusivism was even more dramatic, with $47 \%$ of voters rejecting a non-Muslim governor before the mobilization, $62 \%$ at the height of it in December, and $59 \%$ afterwards). Clearly, Muslim voters hardened their views on the sanctity of Al-Maidah $5^{1}$ during the mobilization. As the defence of AlMaidah $5^{1}$ was the core message of the mobilization, its increased acceptance among Muslims pointed to the success of religio-political entrepreneurs in steering public opinion.

The same picture emerges from the analysis of data on the percentage of Jakarta voters who believed Ahok was guilty of blasphemy. This was the formal focus of the demonstrations. Based on several Indikator surveys conducted in Jakarta during the period of the mobilization, the percentage of Muslim voters who believed Ahok was guilty of blasphemy was particularly high during the months of the three largest street demonstrations, in November 2016 (70\%), December 2016 (63\%), and February 2017 (64\%) respectively. At 63\%, this level remained high after the mobilization, showing how much it had consolidated. Importantly, the surveys consistently showed a very high correlation between belief in Ahok's guilt and voting for his opponents - and indeed, Ahok lost the election mostly as a result of this strong statistical relationship. Once again, these results point to the formidable ability of religio-political entrepreneurs to transform and escalate a set of existing grievances among Muslims into an effective mobilization tool for an Islamist agenda. Ahok's removal and imprisonment, as well as the election of a pro-Islamist governor, would not have been possible without this entrepreneurial capacity of Islamist leaders.

In terms of the secondary message of the Islamist mobilization narrativenamely the perceived economic inequality between Muslims and nonMuslims - the impact of the protests on Muslim attitudes is also clearly visible. In fact, the mobilization was able to overturn a long trend of moderation in this regard. Asked if the economic situation of Muslims was worse than that of non-Muslims, in $201043.4 \%$ of Muslim respondents in an LSI survey responded affirmatively; $38.1 \%$ did so in 2011 ; and just $31 \%$, in 2016 . Evidently, the narrative of there being a massive gap between Muslims and non-Muslims in terms of economic well-being had weakened prior to the mobilization. After the mobilization, however, the percentage of Muslims believing in such a gap increased again to almost $35 \%$, while the percentage of those who did not subscribe to this view dropped from $46.6 \%$ to $40.1 \%$. Through the mobilization, then, religio-political entrepreneurs were able to halt the existing moderation of views, and re-radicalize people's opinions on this subject. After the mobilization, the number of Muslims who believed that they were worse off economically than non-Muslims was almost equal to those who did not. 


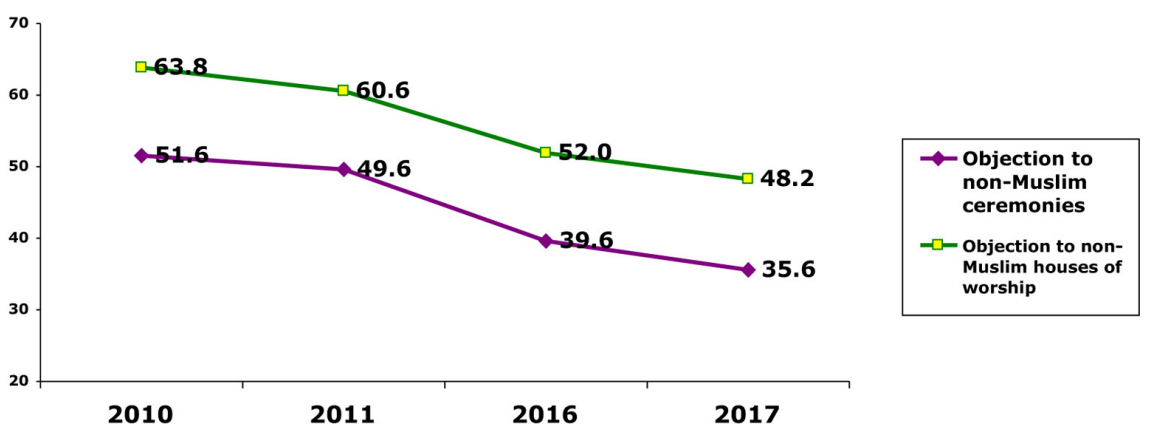

FIGURE 1 Religio-cultural intolerance: Muslim objections to non-Muslim ceremonies and houses of worship (\%), 2010-2017

The success of the mobilization and the religio-political entrepreneurs who drove it is also reflected in support levels for the FPI. Throughout the mobilization, Islamist ideas became embodied in the FPI and its leader, Habib Rizieq. These ideas included the reservation of political office for Muslims; the prioritization of Quranic teachings over the pluralist Indonesian constitution; rejection of Western and Chinese value intrusion; economic redistribution in favour of Muslims; and an expansion of sharia regulations in the Indonesian legal and criminal codes. In LSI's multi-year data set, questions on the awareness of, and support for, the FPI date back to 2004, allowing us to trace the endorsement of FPI ideals among Muslims over time. Between the pre-mobilization survey in March 2016 and the post-mobilization survey in August 2017, support for the agenda of the FPI among the total Muslim population increased from 15.6 to $23.6 \%$ - approximately the same increase we recorded in the number of Muslims objecting to non-Muslims in political positions. The 2017 level was the highest support level for the FPI recorded since September 2006-another piece of evidence for the effectiveness of the religio-political entrepreneurs in propagating their narrative.

At the same time, Muslim attitudes vis-à-vis non-political issues-such as cultural expressions of the Islamic faith and its relation to other religionsremained stagnant or continued to moderate. In two measures in particular, the trend of gradual moderation continued throughout the mobilization. The percentage of Muslims objecting to non-Muslims holding religious ceremonies in their neighbourhood decreased further, from $39.6 \%$ in 2016 to $35.6 \%$ in 2017. Similarly, those objecting to the presence of non-Muslim places of worship in their neighbourhood declined from $5^{2} \%$ prior to the mobilization to $48.2 \%$ afterwards. In both measures of religio-cultural intolerance among Muslims, therefore, the significant trends of moderation that had begun in 2010 continued (see Figure 1). In further tests of this reduction, we found the difference 
between the 2016 and 2017 data to be substantially strong and statistically significant at the $95 \%$ level.

How can we explain this widening gap between hardening political sentiments against non-Muslims on the one hand and softening religio-cultural stances towards non-Islamic faiths on the other? We argue that this divergence is less surprising than it seems. Indeed, it was part of the narrative and appeal of the Islamist mobilization: participants were told that joining the protests did not make them intolerant or racist, and that Islam remained tolerant towards other religions. In a message to his followers prior to the November 2016 demonstration, Rizieq assured them that the protests were not anti-Chinese or anti-Christian, and that the mobilization respected other religions. ${ }^{4}$ This allowed protesters to uphold a self-impression of being tolerant, while at the same time demanding the exclusion of non-Muslims from political office - which Rizieq said was not discrimination, but simply 'an order by my God'. Observers such as Fealy directly witnessed this performative reconciliation between politically exclusivist attitudes and self-assumed religio-cultural tolerance among the December protesters. Fealy (2016) wrote about 'the sense of pride that many attendees felt in the fact that so many Muslims could gather, pray together and then disperse without incident' - their demands for the imprisonment and electoral disqualification of a popular non-Muslim governor notwithstanding.

Other indicators of religious exclusivism remained unchanged after the mobilization. For instance, the LSI developed a radicalism index for the 2016, pre-mobilization poll that measured the potential for radical action (as opposed to Islamist or intolerant attitudes). The index included five measures, ranging from actively supporting movements for the implementation of sharia law to participating in attacks on non-Muslim houses of worship. These measures were assessed in both the actual and the hypothetical dimension: that is, respondents were first asked whether they had participated in an activity, and if the answer was 'no', a second question inquired whether they would do so if the opportunity arose. In the index developed based on the answers to these questions, a score of between 75 and 100 (that is, if a respondent answered all or almost all questions in the affirmative) led to the classification of 'radical'; a score of between 50 to 75 (meaning the respondent answered more than half of the questions positively) denoted 'willing to be radical'; a score of 25 to 50 indicated the categorization 'neutral', while a score of o to 25 denoted 'not willing

4 'Habib Rizieq akhirnya bilang tidak anti Cina dan Kristen, demo 4 November cuma demi ...', 2-11-2016, pojoksatu.id (accessed 25-12-2017). 
to be radical'. Based on these measures, $7.7 \%$ of Indonesians were considered 'willing to be radical' and $0.4 \%$ 'radical'. These numbers changed only slightly post-mobilization, to $9.3 \%$ being 'willing to be radical' and $0.3 \%$ being 'radical'.

While there seemed to be a small increase in the potential for radicalism, this number remained within the margin of error. Put differently, the potential for radical behaviour among the Muslim population was almost entirely unaffected by the Islamist mobilization. This finding supports our earlier decision to exclude violence from Mecham's suggested definition of Islamist political mobilization. We believe it is important to distinguish between Islamist mobilization in a religio-political and ideological sense, and radicalism as carried out by violent and terrorist groups. In our view, the figures cited above further confirm that the 2016 mobilization in Indonesia had all to do with the former, and nothing with the latter.

The overall percentage of Indonesian Muslims supporting ideas of Islamist exclusivism also remained constant after the mobilization. Based on an index that draws on measures of objections to non-Muslims in political positions as well as non-Muslim houses of worship and ceremonies, a similar scoring system to that establishing the radicalism category above was developed (ranging from the lowest score of 'very tolerant' to the highest score of 'very intolerant'). 'Very intolerant' Indonesian Muslims (that is, those who object to almost all forms of non-Muslim engagement in public life, and thus can be classified as Islamist-leaning) made up $27.8 \%$ of the Islamic population in 2016 , and $27.2 \%$ in 2017. (The percentage of 'intolerant' Muslims only slightly increased, from $13.7 \%$ in 2016 to $15 \%$ in 2017 , a statistically insignificant change). However, as we have seen above, the reason for this stagnation has been due to diverging trends in the two main components of the index: while intolerance towards non-Muslims in political office increased sharply, intolerance towards cultural expressions of non-Muslim communities continued to decline, levelling out the overall scores in the index. As argued above, this divide between increasing political intolerance and decreasing religio-cultural intolerance was entirely consistent with the narrative desired by the entrepreneurs of the Islamist mobilization. In fact, it was a crucial part of their message.

The importance of entrepreneurship behind the Islamist mobilization is also reflected in correlations between Islamist attitudes and support for political patrons. From our data, we correlated support for Prabowo and Jokowi with political intolerance (that is, the index of questions on objection to nonMuslims in political office); religio-cultural intolerance (that is, the index developed from two questions on objections to non-Muslim ceremonies and houses of worship); the perception of an economic imbalance between Muslims and 
non-Muslims; and support for the FPI. As shown in Table $2,{ }^{5}$ there is a large and substantive association between support for Prabowo and intolerance; belief in Muslim underprivileging in the economy (referred to as 'relative deprivation'); and support for the FPI. These relationships are statistically significant at the $99 \%$ level. (Conversely, Muslims who support President Jokowi are much more likely to endorse non-Muslims in political office; accept nonMuslim ceremonies and houses of worship; reject that they are economically deprived; and oppose the FPI). Hence, the attitudes researched in our survey draw a clear demarcation line between those who subscribed to the narrative of the Islamist mobilization and supported Prabowo as one of its main religio-political entrepreneurs, and those who rejected the narrative and backed Jokowi — whose perceived secularism irked many Islamist protesters.

The discussion above has shown the importance of comparing pre-mobilization survey data with post-mobilization figures to deliver a comprehensive picture of the drivers and effects of the Islamist street protests in Indonesia. While a set of religious and other grievances existed before the mobilization (and did so for many years), we found no evidence that this caused the mobilization itself. This lack of a causal link between grievances and the mobilization becomes even more obvious when reviewed against multi-year data, which showed declining intensity of the grievances and sentiments before the mobilization began.

We did find data, however, that strongly point to a reverse linkage between the mobilization and rising religio-political grievances and sentiments. We are cautious in making a claim of causality, given the impossibility of providing conclusive statistical evidence for such causality. But we do suggest that the increases in the rejection of non-Muslims in political positions; support for the FPI; and the perception of there being an economic gap between Muslims

5 In this table, the coding and scaling of the variables was done as follows: first, 'support for Prabowo' was coded as $(1)=$ those who supported Joko Widodo; $(2)=$ don't know $/$ no answer; and $(3)=$ those who supported Prabowo. Second, 'political intolerance' was coded as $(1)=$ those who didn't object to non-Muslims in political office; $2=$ neutral; and $3=$ those who objected to non-Muslims in political office. Third, 'religio-cultural intolerance' was coded as $(1)$ = those who didn't object to non-Muslims building houses of worship and holding religious events; $(2)$ = neutral, and $(3)=$ those who objected to non-Muslims carrying out the two religio-cultural activities mentioned above. Fourth, 'relative deprivation' runs from $(1)=$ 'strongly reject that Muslims are economically deprived' to (5) = 'strongly accept the idea of Muslims' economic deprivation'. And fifth, 'support for the FPI' was coded as $(1)=$ knew the FPI and disagreed with its Islamist agenda; $(2)=$ neutral/don't know; and $(3)=$ knew the FPI and supported its Islamist agenda. 


\section{Correlations}

$\begin{array}{lllll}\text { Support for } & \text { Political } & \text { Religio-cultural } & \text { Relative } & \text { Support } \\ \text { Prabowo } & \text { intolerance } & \text { intolerance } & \text { deprivation } & \text { for FPI }\end{array}$

\begin{tabular}{|c|c|c|c|c|c|c|}
\hline \multirow{3}{*}{$\begin{array}{l}\text { Support } \\
\text { for Prabowo }\end{array}$} & Pearson correlation & 1 & $0.182^{* *}$ & $0.114^{* *}$ & $0.072^{* *}$ & $0.163^{* *}$ \\
\hline & sig. (2-tailed) & & 0.000 & 0.000 & 0.007 & 0.000 \\
\hline & $\mathrm{N}$ & 1371 & 1371 & 1371 & 1371 & 1371 \\
\hline \multirow{3}{*}{$\begin{array}{l}\text { Political } \\
\text { intolerance }\end{array}$} & Pearson correlation & $0.182^{* *}$ & 1 & $0.489^{* *}$ & $0.069^{*}$ & $0.15^{2 * *}$ \\
\hline & sig. (2-tailed) & 0.000 & & 0.000 & 0.011 & o.ooo \\
\hline & $\mathrm{N}$ & 1371 & 1371 & 1371 & 1371 & 1371 \\
\hline \multirow{3}{*}{$\begin{array}{l}\text { Religio-cultural } \\
\text { intolerance }\end{array}$} & Pearson correlation & $0.114^{* *}$ & $0.489^{* *}$ & 1 & $0.075^{* * *}$ & o.o69* \\
\hline & sig. (2-tailed) & 0.000 & 0.000 & & o.oo6 & 0.011 \\
\hline & $\mathrm{N}$ & 1371 & 1371 & 1371 & 1371 & 1371 \\
\hline \multirow{3}{*}{$\begin{array}{l}\text { Relative } \\
\text { deprivation }\end{array}$} & Pearson correlation & $0.072^{* *}$ & $0.069^{*}$ & $0.075^{* *}$ & 1 & $0.056^{*}$ \\
\hline & sig. (2-tailed) & 0.007 & 0.011 & 0.006 & & 0.037 \\
\hline & $\mathrm{N}$ & 1371 & 1371 & 1371 & 1371 & 1371 \\
\hline \multirow[t]{3}{*}{ Support for FPI } & Pearson correlation & $0.163^{* *}$ & $0.152^{* *}$ & $0.069^{*}$ & $0.056^{*}$ & 1 \\
\hline & sig. (2-tailed) & 0.000 & 0.000 & 0.011 & 0.037 & \\
\hline & $\mathrm{N}$ & 1371 & 1371 & 1371 & 1371 & 1371 \\
\hline
\end{tabular}

\footnotetext{
${ }^{* *}$ Correlation is significant at the 0.01 level (2-tailed)

* Correlation is significant at the 0.05 level (2-tailed)
}

and non-Muslims after the mobilization are not coincidental. These increases occurred in thematic areas closely linked to the key messages pushed by the mobilization organizers. Thus, we believe it would be implausible not to view the mobilization as the main trigger of the post-protest hardening of Islamist attitudes. This consolidation of Islamist views, in turn, reflects the effectiveness of religio-political entrepreneurs, who did not simply use existing resentments, but re-packaged them into a powerful narrative of mobilization. At the same time, sentiments that the mobilization leaders had either reconciled with, or excluded from, their narrative-such as religio-cultural intolerance or radicalism—remained stagnant or continued to soften. Thus, while grievances 
were an important precondition for the mobilization, it took religio-political entrepreneurs - in the way Mechem described — to turn them into capital for successful Islamist political mobilization.

\section{The Demographics of Mobilization}

Our data also allow us to make some assessments about which demographic groups were most impacted by (that is, attracted to) the mobilization. While the correlations we ran on the 2017, post-mobilization data showed no statistically strong overall relationship between support for Islamist ideas and education and income levels, this in itself is a significant finding, because similar correlations from the 2010 and 2011 data exposed a strong pattern of intolerance rising with declining education and income levels. However, correlations don't tell us much about which group was more vulnerable to Islamist recruitment between the pre- and post-mobilization periods. For this, we have to turn to micro-comparisons between cross tabulations drawn from the 2016 and 2017 surveys, showing us who was more likely to be recruited by the mobilization than others. And indeed, this analysis demonstrated that, across a number of measures, Muslims from lowly educated and poorer groups were more likely to be drawn to Islamist messages by the 2016 mobilization than Muslims from the upper and middle classes.

Before we delve into this microanalysis of cross tabulations on the demographics of the mobilization recruitment, let us summarize findings we have published elsewhere on the pre-mobilization period (Mietzner and Muhtadi 2018). In the 2010 and 2011 LSI surveys on intolerance and Islamist exclusivism, correlations showed patterns consistent with the modernization approach to intolerance and radicalization: that is, that individuals are becoming more tolerant as their income and education levels rise. But in the 2016 LSI premobilization survey, this correlation had entirely disappeared. In fact, when focusing in detail on a number of important measures (such as objection to non-Muslim governors or presidents), cross tabulations showed that lowincome and low-education Muslims were more tolerant than those with high incomes and tertiary degrees. A similar trend was visible in the support patterns for the FPI. How, then, did the mobilization influence these attitudinal structures, and what can we learn from this about the vulnerability of diverse demographic groups to Islamist mobilization?

As in the 2016 survey, an overall correlation exercise across all measures of the 2017 data reveals no statistically relevant relationship between income and education on the one hand and intolerant Islamist attitudes on the other. This 
TABLE 3 Objection to non-Muslims as governors by education level (\%)

\begin{tabular}{lrrrr}
\hline Education level & Base $^{*}$ & 2016 & 2017 & Change \\
\hline Primary school/lower & 45.3 & 39.0 & 47.8 & 8.8 \\
Junior high school & 19.7 & 40.7 & 52.4 & 11.7 \\
Senior high school & 26.3 & 40.5 & 47.5 & 7.0 \\
Higher education & 8.6 & 43.9 & 43.2 & -0.7 \\
\hline
\end{tabular}

\footnotetext{
* Base: The average taken from the 2016 and 2017 survey samples. There are slight differences between this data and that of the Central Statistics Agency (Badan Pusat Statistik, BPS) because of different age and education categories.
}

has two implications: first, it confirms that since 2010 and 2011, the rich and highly educated have formed a proportionally larger share of the Islamist constituency than in previous years, when the lower classes dominated. As we explained earlier, this contributed to the increased organizational capacity of the Islamists in 2016, as highly educated and affluent Islamists in key positions of the state, economy, and society were able to support the mobilization logistically and politically. Second, however, if we want to understand micro-level changes between the pre-mobilization and post-mobilization periods, we need to focus in more detail on individual measures and analyse the cross-tabulation data from there (as we previously did with the 2016 data).

As a sample of political intolerance towards non-Muslims, let us analyse cross-tabulation data on the relationship between objections towards nonMuslims as governors and educational attainment. Overall, the rejection rate among Muslims went up from $40.3 \%$ in 2016 to $48.2 \%$ in 2017 , roughly an $8 \%$ increase. In 2016, $39 \%$ of elementary-school graduates (or lower) objected to non-Muslim governors, while $44 \%$ of tertiary-degree holders did. Generally, there was - in this particular category - a trend of increasing intolerance with increasing education. In 2017, the pattern was reversed: now $48 \%$ of the lowest education group objected to non-Muslim governors, while only $43 \%$ of university graduates did (see Table 3). Thus, while the level of objection towards non-Muslim governors among tertiary-degree holders was unaffected by the mobilization, it increased sharply among less-educated Muslims. Importantly, the highest increase in political intolerance was recorded among the secondlowest education strata, namely junior-high-school graduates. There, the objection rate increased from $41 \%$ to $5^{2} \%$, an above-average increase. As the two lowest education strata make up around $65 \%$ of the Indonesian population, 
the post-mobilization increases in intolerance in these two groups was mainly responsible for the overall spike in this intolerance measure.

A similar trend exists in terms of income. Looking at the measure of objections to a non-Muslim president, the rejection rate overall increased from $48 \%$ in 2016 to $53 \%$ in 2017 . In $2016,51 \%$ of high-to-middle-income earners (above Rp 2 million, or US\$150) objected to a non-Muslim president, as opposed to only $42 \%$ among low-income respondents (below Rp 1 million, or US $\$ 75$ ). Again, there was a trend of increasing intolerance with increasing income. While post-mobilization rejection rates were still smaller among lowincome Muslims, the increase of objections in this income bracket was much higher than among high-income earners. In the lowest bracket, the objection rate jumped from $41.5 \%$ to $50 \%$-almost double the amount of the general increase. In the highest bracket, the increase in objection towards non-Muslims as president was below average at only $3 \%$-from $5^{1}$ to $54 \%$. Thus, as in the education segment, the microanalysis of income patterns shows that lowerclass Muslims were more vulnerable to being recruited by the mobilization narrative than the upper classes. As we argued earlier, members of these upper classes were crucial in the mobilization (Mietzner and Muhtadi 2018), but our new data show that if affluent citizens had not been 'converted' to the cause prior to the mobilization, then they were less likely to be persuaded as a result of it.

Education-level analyses of support for the FPI deliver more complex, but comparable results. Recall that overall support for the FPI among Muslims increased from $15.6 \%$ before the mobilization to $23.6 \%$ afterwards. Prior to the mobilization, in 2016, 18.7\% of Muslims with a tertiary degree supported the FPI, while only $8.2 \%$ of Muslims with an elementary-school degree (or less) did. A pattern of increasing support for the FPI with increasing education existed. After the mobilization that pattern was maintained, with $34.3 \%$ of Muslim university graduates backing the FPI, compared to $15.3 \%$ of lowly educated Muslims. But because low-education citizens make up a much larger pool of the Muslim population ( $49 \%$ versus $8 \%$ in the 2017 survey sample), the increase in this strata was numerically more significant than in the high-education segment. Concretely, the number of FPI supporters with an elementary-school degree (or less) as a percentage of the total Muslim population increased from $3.5 \%$ before the mobilization to $7.4 \%$ afterwards. By contrast, the percentage of FPI sympathizers with a tertiary degree increased only from $1.7 \%$ before the mobilization to $2.8 \%$. (Note that the percentages for the various education brackets differed slightly in the 2016 and 2017 surveys). Thus, in total numbers, more lowly educated Muslims were drawn to the FPI after the mobilization compared to highly educated Muslims. 
Investigating income patterns in the 'support for the FPI' measure compliments this picture. In 2016, $20.1 \%$ of high- and middle-income Muslims supported the FPI, while only $7.5 \%$ of low-income Muslims did. After the mobilization, these percentages went up to 28.5 and 16.3 respectively. In other words, the post-mobilization increase of support for the FPI among low-income Muslims was proportionally and in total terms larger than among high-income Muslims. Among poorer Muslims support levels more than doubled, while in the more affluent segment the increase was according to the overall development curve.

These statistics correspond with qualitative observations of the way the mobilization unfolded and who was targeted. While the street protesters were mostly educated, middle-class Muslims, they often belonged to religious groups that either drove, or sympathized with, the mobilization. By contrast, the grassroots network attached to the mobilization organizers targeted those who initially felt less drawn to the protests: workers, housewives, food stall owners, and so forth. The main avenues for reaching these lower-class Muslims were local mosques (Berenschot 2017; Kuipers 2017). Pitched to influence ordinary Muslims, preachers told congregations - particularly in Jakarta, but elsewhere too- that whoever supported Ahok would not enter heaven. Some mosques even produced banners saying that Ahok sympathizers would not receive funeral services from local clerics after their death. Lower-class Muslims interviewed by the authors stated that they became convinced that they would 'go to hell' if they supported Ahok or disputed the validity of AlMaidah $51{ }^{6}$ Thus, while generally tolerant towards non-Muslim neighbours, these lower-class Muslims came to endorse the exclusion of non-Muslims from political office as a result of the message of moral punishment and shaming that the mobilization organizers directed specifically towards them. The data clearly reflect this trend.

Our data are also consistent with observations of urban poor being drawn to Islamist recruitment efforts by highly targeted criticisms of some of Ahok's neo-liberal modernization policies. In particular, Ahok's evictions of some slum settlements had angered many urban poor affected by these evictions, and they often turned to Islamist groups as these were the only ones prepared to pay attention to them (Törnquist 2017:136). Over time, their specific policy grievances transformed into more general sentiments against nonMuslims (and Chinese) in political positions (Wilson 2016, 2017). While this phenomenon was mostly limited to directly affected communities, our data suggest that the narrative of Ahok and other non-Muslim or Chinese office

6 Interview with a domestic helper from Central Jakarta, 23-4-2017. 
holders being hostile to the poor spread across Jakarta's geographic and specific community borders. Once again, the role of religio-political entrepreneurs was decisive, with Islamist 'supporter networks (including hardline clerics) [...] exploiting anxieties and material hardship via rhetoric that mixes critiques of neoliberalism and democracy with xenophobia' (Wilson 2017).

Accordingly, while macro-level correlation statistics do not show a general relationship between Islamist attitudes on the one hand and education and income levels on the other, analyses of micro-level cross tabulations provide solid indications that poorer Muslims were drawn in greater numbers to the mobilization message than their more affluent counterparts. The latter, as shown previously, played a larger role in the organization of the mobilization, but low-class Muslims were more susceptible to its impact. This, in turn, points once again to the importance of religio-political entrepreneurs in designing and enforcing the mobilization narrative. It also demonstrates the manipulability of grievances and religious sentiments, which can be escalated or deescalated in line with the strategic goals of mobilization organizers and the political interests associated with them.

\section{The Government Response: Accommodation and Repression}

The Jokowi government responded in two ways to the Islamist mobilization. Like many other governments trying to mitigate Islamist or similar populist challenges, the Indonesian administration applied both accommodation and repression. As we show in this section, while the government's actions have temporarily undercut the Islamists' ability to mobilize, they have not reduced their popularity or the attractiveness of their ideas. Moreover, both the accommodation and the repression elements of the government response have reduced Indonesia's democratic quality, and have put the country on a path of democratic deconsolidation. This process, defined as one in which democratic 'rules that were once respected by all important political players [...] suddenly come under attack' (Foa and Mounk 2016:15) has also been described as Indonesia's 'illiberal turn' (Hadiz 2017).

Through the first element of its response - that is, accommodation - the government tried to reduce the Islamists' pressure by adopting some of their themes and demands. To begin with, after the first large demonstration in November 2016, the palace ordered the police to indict Ahok, despite the investigators' earlier findings that no case existed. This religious politicization of the justice apparatus not only set a dangerous precedent for future cases of this kind, it also failed to have any impact on the demonstrators. Rather than 
reducing their activity, they staged an even larger demonstration in December, this time demanding Ahok's arrest (Fealy 2016). At that protest, Jokowi continued to accommodate them, even appearing and briefly speaking at the rally. Subsequently, he increased the frequency of his visits to Islamic organizations and boarding schools; gave positions to Islamic critics of his government; promised to include Muslim groups and individuals as beneficiaries of his land re-distribution programme to address the inequality issue; and treaded a more careful line on topics important to Islamic conservatives, ranging from investigations into the 1965 massacre (in which Muslim groups played a key role) to the position of religious minorities and how to deal with the country's LGBTI community.

The government's accommodation approach was complemented, however, by repression of the most hard line Islamist elements (Hadiz 2017). The apparent goal of this dual strategy was to split off more mainstream Islamic leaders from the Islamist mobilization. The moderates willing to disengage from the mobilization were rewarded, while the remaining core leaders were repressed. Although repression is part of the strategy that some theorists recommend to counter populist challenges (Rummens and Abts 2010), these authors insist that such repression must take place within legal and democratic boundaries (Mueller 2012). The Jokowi government, by contrast, used highly questionable, and often fabricated, legal cases to pursue its repression of actors involved in the Islamist mobilization. One of our authors has described these measures and their impact on the quality of democracy in detail (Mietzner 2018), but it is useful to quickly outline three broad sets of actions taken by the government. First, treason charges were laid against some protest leaders, based on the dubious suggestion that the demonstrations tried to overthrow the government. Second, other legal cases unrelated to the protests were brought against the main organizers of the mobilization. In Rizieq's case, he was charged with pornography over a smartphone conversation with a female companion. And third, the government banned the Indonesian branch of Hizbut Tahrir after issuing an emergency regulation that abolished the judicial process normally required to implement such a ban.

The impact of the government's accommodation-and-repression approach has been mixed and complex. On the one hand, there is little doubt that the repression reduced the ability of the Islamists to mobilize. The protests' charismatic leader, Rizieq, self-exiled to Saudi Arabia, and, at the time of writing, remained there. As a result, the movement became leaderless, with a retired politician (former presidential candidate Amien Rais) taking Rizieq's position but unable to match his mobilizational charisma. Thus, the street protests became much less regular and much smaller in size (a significant rally in 
December 2017 to commemorate the large protests a year earlier notwithstanding). The ban of HTI also disrupted that organization's Islamist recruitment operations, particularly on campuses. HTI had not been the main component of the movement behind the mobilization of 2016, but it had played a significant role. Thus, paralysing this group had an impact on the overall mobilizational capacity of Islamists, and it sent a warning signal to other groups in the network that they, too, could be banned.

Moreover, the government achieved this disruption of the Islamist network at little political cost. HTI's ban triggered no strong resistance among the Muslim community (indeed, some large Muslim groups openly welcomed the shutting down of a long-standing rival). Our data show that among those Muslims who had heard about the government's emergency regulation that facilitated the ban, $57 \%$ agreed with it being used against HTI, while only $22 \%$ objected.

But as the data presented in this article demonstrated, the measures taken by the government have had no effect on the popularity of major Islamist ideas and groups. The notion that non-Muslims should not hold important political positions hardened during the mobilization and persisted long after repressive measures had been taken against the main promoters of these ideas. Similarly, support levels for the FPI shot up during the mobilization and remained high, even after Rizieq's going into exile. Using a data point collected by SMRC, we can show that the FPI's popularity among Indonesian Muslims jumped to $22.4 \%$ in November 2016, at the height of the mobilization (up from $15.6 \%$ in the March 2016 LSI survey). Eight months later, in our August 2017 LSI survey, that level had remained steady (in fact, it increased to 23.6\%). In short, despite the charges against, and self-exiling of, Rizieq; despite the measures taken against other Islamist leaders; despite the ban of a key Islamist organization; and despite the weakening of the street mobilization, the hardening of Islamist attitudes among Muslims - and support for the main group representing them - endured in the post-mobilization period.

Hence, while the government has been able to contain the immediate political and organizational fall-out from the Islamist mobilization through a mix of accommodation and repression, the attitudinal impact of the 2016 events appears to be long-lasting. Clearly, core Islamist ideas have consolidated among the Muslim population since the mobilization. This points to the success of the religio-political entrepreneurs, who were working towards such a hardening of Islamist attitudes. But it also highlights that Indonesia's Muslim community (long viewed as inherently moderate) has become highly susceptible to exclusivist ideas. 


\section{Islamist Mobilizations: Lessons from the Indonesian Case}

Let us now return to the general debate on what causes Islamist mobilizations. Recall that we divided existing schools of thought on this subject into three broad camps: first, those who emphasized the importance of grievances and exclusivist sentiments as triggers of mobilization; second; authors who believed that mobilization is inherent to Islamic faith and ideology; and third, scholars who stress how religio-political entrepreneurs use grievances and Islamic ideas to pursue their Islamist mobilization agenda. In the context of this debate, the Indonesian case can help us understand what causes Islamist mobilizations, and what doesn't.

In terms of grievances and specific exclusivist sentiments, it is important neither to downplay nor to overstate them. It is indisputable that Muslim grievances and a religio-political sense of deprivation are important ingredients of any Islamist mobilization. Thus, there has to be a foundation of such grievances in a society for Islamist mobilization to work. These grievances can, as explained, include feelings of Muslims being worse off than non-Muslims economically, or of non-Muslims taking a disproportionate share of political positions. These perceptions can be, and often are, intermixed with a general anxiety that the sanctity of the faith is under attack. But as we have seen in the Indonesian case, this set of sentiments existed long before the mobilization, and many of those sentiments were becoming more moderate over time, not more radical. Further, and crucially, we suggested that the hardening of sentiments was not the cause, but the effect of the mobilization. This indicates that grievances and sentiments are mouldable items, vulnerable to much manipulation by religio-political entrepreneurs.

The same is true of core elements of the Islamic faith per se, which the second group of scholars holds responsible for Islamist mobilizations. Without these doctrinal elements derived from Islamic scripture, Islamist mobilization would not occur. But the Indonesian case has shown how quickly key beliefs can harden as a result of mobilization, rather than being the cause of the mobilization. The main message of the Islamist mobilization formed around a Quranic verse, Al-Maidah 51 . The content of this verse has been hotly contested in the Muslim world, and especially in Indonesia. One literal translation offered is:

O you who believe! Do not take friends from the Jews and the Christians, as they are but friends of each other. And if any among you befriends 
them, then surely, he is one of them. Verily, Allah guides not those people who are the wrongdoers. ${ }^{7}$

In the Indonesian context, however, Islamists have re-interpreted the term 'friends' as 'leaders'. Subsequently, they extrapolated from this that non-Muslims are barred from holding political office, and that Muslims are obliged not to vote for non-Muslim candidates in elections (Menchik 2016). As we have seen, the number of Indonesian Muslims adopting this view rose sharply after the mobilization, which heavily propagated a narrow Islamist interpretation of the verse. Once again, this post-mobilizational change in attitudes does not point to the inherent power of the Quranic verse itself, but to the ability of religio-political entrepreneurs in shaping public views of it.

The Indonesian case, then, provides much support for Mecham's notion of religio-political entrepreneurship behind Islamist mobilizations. The influence of these entrepreneurs was particularly quantifiable in the Indonesian case, because of the clearly defined time frame of the mobilization (several months as opposed to many years in other cases) and the precise nature of its narrative (blasphemy charges against a non-Muslim governor, the sanctity of Al-Maidah 51, and economic inequality). By comparing support levels for this narrative before, during, and after the mobilization, it was possible to systematically insulate drivers and effects of the protests. As stated above, we could rule out specific grievances and convictions as causes of the mobilization, as attitudes to these were softening when it occurred; but we could establish that after the mobilization an additional 7 to $8 \%$ of the Muslim population subscribed to exactly those messages of the Islamist agenda that the mobilization organizers promoted (that is, the rejection of non-Muslims in political positions). Not coincidentally, there was also an $8 \%$ increase in the support levels for the group chaired by the main leader of the protests. We propose that this addition of around $8 \%$ to the constituency of Muslims endorsing ideas of religio-political exclusivism (ideas which form the core of Islamism as an ideology) was a direct effect of the mobilization.

It is tempting to view these findings as a recommendation to governments interested in stemming the rise of Islamism that they need to disrupt mobilizations. After all, we have shown that the consolidation of Islamist views in Muslim populations is more likely to be the effect of mobilizations than

7 This translation is from the Verse by Verse Qur’an Study Circle, https: //versebyversequranstudycircle.wordpress.com/2013/o3/o5/tafseer-surah-al-maidah-ayah $-51 /($ accessed 20-12-2017). 
the cause of them. But it is worth recalling the experience of countries that have tried a repressive mobilization-disruption approach. Egypt, for example, repressed the Muslim Brotherhood's mobilization potential for decades, only for the organization to record a landslide electoral victory once the repression was lifted (Trager 2016). The current repression of the Brotherhoodafter the democratic experiment collapsed-is unlikely to produce different results. Moreover, illiberal repression tends to breed further illiberalism in the polity and society. This is a risk to which the Jokowi government has exposed Indonesian democracy as well, with its repressive measures leading to an erosion of democratic quality. The only way to disrupt Islamist mobilization without damaging democracy, then, is by applying politico-legal mechanisms within the corridors of the very democracy that the government claims to defend (Mueller 2012). This can include banning organizations with an openly anti-democratic agenda, but only through a thorough, judicial process. In defending themselves, democracies must be fierce, but also fiercely lawabiding.

\section{References}

Assyaukanie, Luthfi (2017). 'Unholy alliance: Ultra-conservatism and political pragmatism in Indonesia', Thinking ASEAN 19, January. Available at http://thcasean.org/ read/articles/327/Unholy-Alliance-Ultra-Conservatism-and-Political-Pragmatismin-Indonesia (accessed 5 April 2018).

Berenschot, Ward (2017). 'Ahok's defeats and public debate in Indonesia', New Mandala, 18 May. Available at http://www.newmandala.org/ahoks-defeats-say-public-debate -indonesia/ (accessed 29 November 2017).

Bouyahya, Driss (2015). 'Islamist movements in Morocco and their typology', European Scientific Journal 1:1:1-9.

Eligür, Banu (2010). The mobilization of political Islam in Turkey. Cambridge: Cambridge University Press.

Esposito, John L. and Dalia Mogahed (2008). 'Who will speak for Islam?', World Policy Journal 25-3:47-57.

Fealy, Greg (2016). 'Bigger than Ahok: Explaining the 2 December mass rally', Indonesia at Melbourne, 7 December. Available at: http://indonesiaatmelbourne.unimelb.edu .au/bigger-than-ahok-explaining-jakartas-2-december-mass-rally/ (accessed on 29 November 2017).

Foa, Roberto S. and Yascha Mounk (2016). 'The danger of deconsolidation: The democratic disconnect', Journal of Democracy 27-3:5-17.

Fuller, Graham and Marcel Kurpershoek (2005). What future for political Islam? Dilem- 
mas and opportunities for the next decade. The Hague: WRR/Scientific Council for Government Policy.

Hadiz, Vedi R. (2016). Islamic populism in Indonesia and the Middle East. Cambridge: Cambridge University Press.

Hadiz, Vedi R. (2017). 'Behind Indonesia's illiberal turn', New Mandala, 20 October. Available at http://www.newmandala.org/indonesia-illiberal/ (accessed 27 December 2017).

Hadiz, Vedi R. and Richard Robison (2017). 'Competing populisms in post-authoritarian Indonesia', International Political Science Review 38-4:488-502.

Kepel, Gilles (2006). Jihad: The trail of political Islam. London: Tauris.

Kuipers, Nick (2017). 'Mosque polling stations and voting for Anies', New Mandala, 7 November. Available at http://www.newmandala.org/anies-mosque-tps/ (accessed 20 January 2018).

Lindsey, Tim (2016). 'Blasphemy charge reveals real fault lines in Indonesian democracy', Indonesia at Melbourne, 25 November. Available at http://indonesiaatmelbourne.unimelb.edu.au/blasphemy-charge-reveals-real-fault -lines-in-indonesian-democracy/ (accessed 15 November 2017).

Lindsey, Tim (2017). 'Ahok's defeat bodes ill for the future', Indonesia at Melbourne, 20 April. Available at http://indonesiaatmelbourne.unimelb.edu.au/ahoks-defeat -bodes-ill-for-the-future/ (accessed 7 December 2017).

Marsden, Peter V. and James D. Wright (2010). Handbook of survey research. Bingley: Emerald Group Publishing.

Mecham, Quinn (2017). Institutional origins of Islamist political mobilization. Cambridge: Cambridge University Press.

Menchik, Jeremy (2016). "'Do not take unbelievers as your leaders": The politics of translation in Indonesia', Mizan, 31 March. Available at http://www.mizanproject .org/do-not-take-unbelievers-as-your-leaders/ (accessed on 19 November 2017).

Mietzner, Marcus (2018). 'Fighting illiberalism with illiberalism: Islamist populism and democratic deconsolidation in Indonesia', Pacific Affairs 91-2:262-81.

Mietzner, Marcus and Burhanuddin Muhtadi (2018). 'Explaining the 2016 Islamist mobilisation in Indonesia: Religious intolerance, militant groups and the politics of accommodation', Asian Studies Review 42-3.

Mueller, Jan-Werner (2012). 'Militant democracy', in: Michel Rosenfeld and Andras Sajó (eds), The Oxford handbook of comparative constitutional law. Oxford: Oxford University Press.

Murphy, John F. (2002) Sword of Islam: Muslim extremism from the Arab conquests to the attack on America. Amherst, NY: Prometheus.

Pew Research Center (2013). The world's Muslims: Religion, politics and society. Washington: Pew Research Center.

Roy, Olivier (2017). 'Political Islam after the Arab Spring: Between Jihad and democracy', 
Foreign Affairs, November/December. Available at https://www.foreignaffairs.com/ reviews/review-essay/2017-10-16/political-islam-after-arab-spring (accessed 5 January 2018).

Rummens, Stefan and Koen Abts (2010). 'Defending democracy: The concentric containment of political extremism', Political Studies 58:649-65.

Setijadi, Charolotte (2017). Chinese Indonesians in the eyes of the pribumi public. Singapore: ISEAS Yusof Ishak Institute. [Perspectives 73.]

Sumaktoyo, Nathanael (2018). 'Measuring religious intolerance across Indonesian provinces', New Mandala, 1 June 2018. Available at http://www.newmandala.org/ measuring-religious-intolerance-across-indonesian-provinces/ (accessed 2 June 2018).

Tibi, Bassam (2014). Political Islam, world politics and Europe: From Jihadist to institutional Islamism. London: Routledge.

Törnquist, Olle (with Hasrul Hanif, Eric Hiariej, Willy P. Samadhi and Amalinda Savirani) (2017). 'The downside of Indonesia's successful liberal democratisation and the way ahead: Notes from the participatory surveys and case studies, 2000-2016', Journal of Current Southeast Asian Affairs 36-1:123-38.

Trager, Eric (2016). Arab Fall: How the Muslim Brotherhood won and lost Egypt in 891 days. Washington: Georgetown University Press.

Waardenburg, Jacques (2002). Islam: Historical, social and political perspectives. Berlin and New York: Walter de Gruyter.

Wickham, Carrie Rosefsky (2002). Mobilizing Islam: Religion, activism and political change in Egypt. New York: Columbia University Press.

Wilson, Ian (2016). 'Making enemies out of friends', New Mandala, 3 November. Available athttp://www.newmandala.org/making-enemies-friends/ (accessed 1o December 2017).

Wilson, Ian (2017). 'Jakarta: Inequality and the poverty of elite pluralism', New Mandala, 19 April. Available at http://www.newmandala.org/jakarta-inequality-poverty-elite -pluralism/ (accessed 23 November 2017). 